\title{
Performance of Italian ryegrass varieties: Effect of cutting stage on dry matter and total non-structural carbohydrates percentages
}

\begin{abstract}
Patrick N Rakau ${ }^{1 *}$, Khuliso E Ravhuhali², Mpho Nzeru ${ }^{1}$
${ }^{1}$ Agricultural Research Council, Cedara, Animal Production Institute, Forage Breeding, P.O. Box 1055, Hilton 3245, Kwazulu Natal, South Africa

${ }^{2}$ School of Agriculture Sciences, Department of Animal Science, Faculty of Natural and Agricultural Sciences, North-West University, Private Bag X2046 Mmabatho, 2735, South Africa

\section{Abstract}

Plant dry matter (DM) is one of the most limiting factors on the rumen fill. Due to variation in seasons, forages are prone to different stresses ranging from abiotic and biotic factors. The study was done to assess the effect of cutting stage on dry matter yield $r$ and total non-structural carbohydrates of Italian ryegrass varieties (14 varieties). Diploid varieties namely: Supercharge, Sukari, Kigezi, Bartrento, ARC-148 BQX, Maximus and 14 LMD 43 and Tetraploid varieties namely: Green-Spirit, Barmulta II, ARC-214 GQX, Supreme Q, Agriton, AgriBoost and Mona. The trial was run at the Cedara research station in KwaZulu-Natal province (KZN). All 14 varieties were planted in rows which were $150 \mathrm{~mm}$ apart (at the population rate of $30 \mathrm{~kg} / \mathrm{ha}$ for both diploid and tetraploid) replicated three times in a laid out and fitted into randomized complete block design (RCBD). Dry matter yield and non-structural carbohydrates were analysed. A consistent effect of cutting stage on DM yield and TNC was not observed on average mean values. The cutting interval did not influence the DM yield and TNC concentration of both on diploid and tetraploid Lolium multiflorum varieties. The cutting stages can be reduced to four or five to allow the plant to regain its vigour after cutting /defoliation in order to and enforce the source-sink relationships.
\end{abstract}

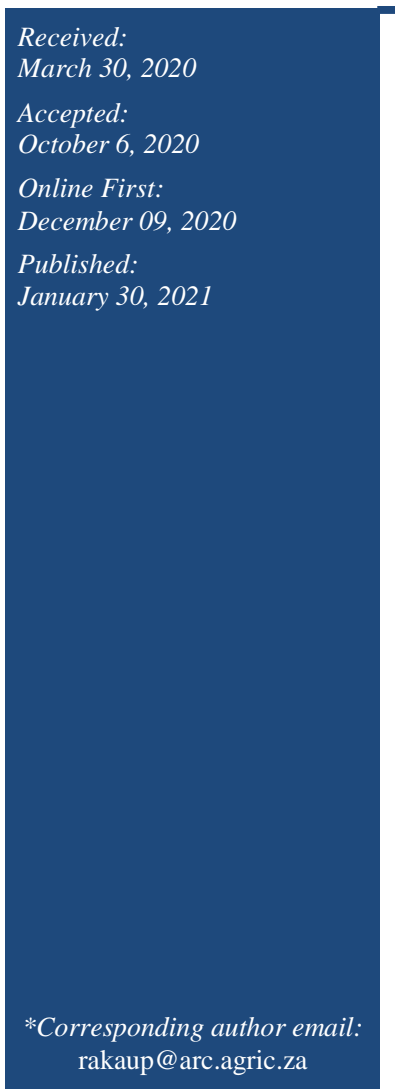

Keywords: Rumen fill, Ruminant, Dairy cattle, Carbohydrates, Linear regression

\section{How to cite this:}

Rakau PN, Ravhuhali KE and Nzeru M, 2021. Performance of Italian ryegrass varieties: Effect of cutting stage on dry matter and total non-structural carbohydrates percentages. Asian J. Agric. Biol. 2021(1). DOI: https://doi.org/10.35495/ajab.2020.02.116

This is an Open Access article distributed under the terms of the Creative Commons Attribution 3.0 License. (https://creativecommons.org/licenses/by/3.0), which permits unrestricted use, distribution, and reproduction in any medium, provided the original work is properly cited.

\section{Introduction}

One of the significant plant's responses to different stresses is changes in carbohydrates reserves such as TNC contents due to defoliation and variations in climatic conditions, which also had an impact on dry matter yield. The total non-structural carbohydrates are known to be translocated within the plant and used for growth, respiration, and they are essential in the recovery of plants from disturbances. Large quantities of soluble carbohydrates, predominantly fructans are stored in the vacuoles of the leaf and crown tissues during cold conditions (Huner et al., 1993). Previous reports indicated an increment in TNC percentages on forages when sheep grazed plants and these commonly influence rumen fermentation thereby enhancing rumen nitrogen degradation and aid in the nitrous oxide emissions reduction in pastures 
(Michell, 1973; Jones and Roberts, 1991; Harrison et al., 2011). Fructan polymers are regarded as the principal storage of carbohydrates (Pontis, 1989; Price et al., 2002). To maintain high DM intake by livestock, 18 to $20 \%$ of DM should be maintained to maximize the productivity of ruminants (NRC, 2000). According to Regional Climate Development under Global Warming (regclim, 2005) DM intake can vary due to seasonal variations. Cutting is known to influence DM production and quality of plant (Wadi et al., 2004). The amount of residual leaf area must be adequate for continuing photosynthesis to get significant re-growth (Grace et al., 2019). Photosynthesis can be significantly inhibited with the removal of leaf tissue because green tissue is required for photosynthesis. Dry matter yield normally increases with decreasing disturbances (Tessema et al., 2010). Therefore, the objective of this study was to investigate the effect of cutting stage on dry matter, and non-structural carbohydrates of fourteen (14) selected Italian ryegrass varieties (tetraploid and diploid).

\section{Material and Methods}

\section{Study site}

Experiment was conducted at KwaZulu-Natal Cedara research station, South Africa. The site is located at $29^{\circ} 32^{\prime} \mathrm{S} 30^{\circ} 16^{\prime} \mathrm{E}$ at an altitude of $1075 \mathrm{~m}$ above sea level and the average annual rainfall of $885 \mathrm{~mm}$. The average high temperature is $16.2{ }^{\circ} \mathrm{C}$, and low temperature in winter was $3.7^{\circ} \mathrm{C}$. Frost periods on average, is 75 days per annum. The soil at the experimental farm had 10.5, 97.5, 790, 211, 2.0, 4.5 and $2.45 \mathrm{mg} / \mathrm{L}$ for $\mathrm{P}, \mathrm{K}, \mathrm{Ca}, \mathrm{Mg}, \mathrm{Zn}, \mathrm{Mn}$ and $\mathrm{Cu}$, respectively and soil $\mathrm{pH}(\mathrm{KCL})$ was 4.47 . The soil also recorded $4.0,0.275$ and $50.5 \%$ for $\mathrm{OC}, \mathrm{N}$ and clay, respectively.

\section{Experimental design}

The experimental design was laid out and fitted into a randomized complete block design (RCBD) factorial arrangement with three replicates. The experiment consisted of 21 plots, and gross plot size of $2 \mathrm{~m} \times 6 \mathrm{~m}$ and $1.4 \mathrm{~m} \times 4.6 \mathrm{~m}$ was used at the site. From 36 Italian ryegrass varieties both tetraploid and diploid planted on the $14^{\text {th }}$ March 2018, only 14 varieties were selected (seven diploids and seven tetraploid varieties). The following varieties were used: Tetraploid = ARC-214 GQX, Supreme Q, AgriBoost, Green-Spirit, Agriton, Mona and Barmulta II and Diploid $=$ Kigezi,
Supercharge, Sukari, ARC-148 GQX, Bartrinto, 14 LMD 43 and Maximus. All 14 varieties were planted in rows which were $150 \mathrm{~mm}$ apart at the sowing rate of $30 \mathrm{~kg} / \mathrm{ha}$ for both diploid and tetraploid varieties. Twenty-five millimetres per week irrigation was applied. Fertilization of $50 \mathrm{~kg} \mathrm{~N} / \mathrm{ha}$ as 1:0:1 was applied when the seedlings were $10 \mathrm{~cm}$ height and after each cut. The plots were cut seven times from March to November and were cut at 3-leave stage which represents elongation and ready for grazing. Cutting stages were: Cut 1, $11^{\text {th }}$ May 2018; Cut 2, $13^{\text {th }}$ June 2018; Cut 3, $13^{\text {th }}$ July 2018; Cut 4, $28^{\text {th }}$ August 2018; Cut 5, $2^{\text {th }}$ September 2018; Cut 6, $23^{\text {rd }}$ October 2018 and Cut 7, 26 ${ }^{\text {th }}$ November 2018. Cutting were done with Agri-mower machine set at $5 \mathrm{~cm}$ above ground level.

The following equations were adopted to calculate dry matter (DM) yield and total non-structured carbohydrates (TNC).

Dry Matter Yield $=[P G W(S D W / S G W) /$ 1000] $X 10$ 000, were $\mathrm{PGW}=$ Net plot green weight, $\mathrm{SGW}=$ sample green weight and SDW = sample dry weight.

TNC $(\mathrm{g} / \mathrm{kg})=$ Absorbance sample/ absorbance standard X 5555.55 DM \% sample

Total non-structural carbohydrate was analyzed using standard wet chemistry as described by Marais et al. (1966). Chemical Reagents: 0.05 M sulfuric acid reagent solution was prepared through slowing adding concentrated $\mathrm{H}_{2} \mathrm{SO}_{4}(2.8 \mathrm{ml})$ to distilled $\mathrm{H}_{2} \mathrm{O}(500 \mathrm{ml})$ and further diluted to $1 \mathrm{~L}$. $0.1 \mathrm{M}$ Sulfuric acid solution reagent was done through slowing adding concentrated $\mathrm{H}_{2} \mathrm{SO}_{4}(0.56 \mathrm{ml})$ to distilled $\mathrm{H}_{2} \mathrm{O}(50 \mathrm{ml})$ and further diluted to $100 \mathrm{ml}$. Copper reagent solution I was prepared by were dissolving $\mathrm{Na}_{2} \mathrm{CO}_{3}(30 \mathrm{~g})$, $\mathrm{NaHCO}_{3}(20 \mathrm{~g}), \mathrm{KNaC}_{4} \mathrm{H}_{4} \mathrm{O}_{6} .4 \mathrm{H}_{2} \mathrm{O}(15 \mathrm{~g})$ and $\mathrm{Na}_{2} \mathrm{SO}_{4}$ ( $180 \mathrm{~g}$ ) in distilled $\mathrm{H}_{2} \mathrm{O}(1 \mathrm{~L})$. Copper reagent solution II was prepared through dissolving $\mathrm{Na}_{2} \mathrm{SO}_{4}(45 \mathrm{~g})$ and $\mathrm{CuSO}_{4} .5 \mathrm{H}_{2} \mathrm{O}(5 \mathrm{~g})$ in distilled $\mathrm{H}_{2} \mathrm{O}(250 \mathrm{ml})$. Immediately before use, four volumes of solution I was mixed with 1 volume of solution II. The Arsenomolybdate reagent solution was prepared by dissolving $\left(\mathrm{NH}_{4}\right)_{6} \mathrm{Mo}_{7} \mathrm{O}_{24} .4 \mathrm{H}_{2} \mathrm{O}(25 \mathrm{~g})$ in distilled $\mathrm{H}_{2} \mathrm{O}$ $(400 \mathrm{ml})$ and concentrated $\mathrm{H}_{2} \mathrm{SO}_{4}(21 \mathrm{ml})$ was carefully added. The $\mathrm{HNa}_{2} \mathrm{O}_{4} \cdot 7 \mathrm{H}_{2} \mathrm{O}(3 \mathrm{~g})$ was dissolved in distilled $\mathrm{H}_{2} \mathrm{O}(25 \mathrm{ml})$ and added to the acidic ammonium molybdate solution and made up to $500 \mathrm{ml}$. The solution was incubated at $37{ }^{\circ} \mathrm{C}$ for 48 hours and stored in a glass-stoppered brown bottle. For $0.1 \mathrm{M}$ sugar standard, glucose $(0.6667 \mathrm{~g})$ was dissolved in distilled $\mathrm{H}_{2} \mathrm{O}(200 \mathrm{ml})$. 


\section{Procedure}

The plant material $(0.3 \mathrm{~g})$ samples were weighed into test-tube, $0.05 \mathrm{M} \mathrm{H}_{2} \mathrm{SO}_{4}(10 \mathrm{ml})$ was added in each test-tube and mixed respectively. Both blank and standard solutions were prepared, blank contained $0.05 \mathrm{M} \mathrm{H}_{2} \mathrm{SO}_{4}(10 \mathrm{ml})$ without plant material, and the standard solution contained $0.1 \mathrm{M} \mathrm{H}_{2} \mathrm{SO}_{4}(5 \mathrm{ml})$ and sugar standard $(5 \mathrm{ml})$. Both solutions were heated in a boiling water bath for 30 minutes, cooled to room temperature immediately, transferred quantitatively to a $250 \mathrm{ml}$ volume flask. Both solutions were filtered before analyzing for reducing sugars tests. Samples were filtered to $1 \mathrm{ml}$ volume each and diluted to $3 \mathrm{ml}$ volume with distilled water. Standard and blank testtube solutions containing $3 \mathrm{ml}$ aliquots of standard sugar solution and $3 \mathrm{ml}$ of distilled water, respectively. Copper mix solution of $3 \mathrm{ml}$ was added to each solution and mixed well, heated in a boiling water bath for 20 minutes and cooled at room temperature. The Arsenomolybdate reagent of $3 \mathrm{ml}$ was added and shaken until bubbles formation ceased. The colour appeared after 1.5 hours, and the solution was transferred to $200 \mathrm{ml}$ volume flask. The absorbance was read at $750 \mathrm{~nm}$ against the blank solution.

\section{Statistical analysis}

Analysis of variance (SAS, 2010) was used to assess the effect of cutting and variety on DM and TNC data. The least square means were compared using Tukeys test. The least significant difference test was performed at a $\mathrm{P}<0.05$ level of probability to establish the significant difference between treatments means.

\section{Results and Discussion}

Results reflecting average TNC and DM values for varieties and the different cutting stages of seven selected Italian ryegrass varieties of diploid and tetraploid are presented in Table 1. Within species, the SuperCharge variety exhibited higher $(\mathrm{P}<0.05) \mathrm{DM}$ (21\%) and TNC (23.1\%) as compared to all other varieties in the diploid group. These TNC values in all varieties are comparable with the previous report by Francis et al. (2002). The diploid varieties TNC values different cutting stages from ranged from 12 to $20 \%$. Indeed, different varieties can have variation in TNC and DM yield. Except for Mona variety, GreenSpirit in tetraploid had the same $(\mathrm{P}>0.05) \mathrm{DM}$ value as all other varieties under the same tetraploid group.
SupremeQ in tetraploid had the highest $(\mathrm{P}<0.05) \mathrm{TNC}$ value $(16.7 \%)$ when compared to other varieties.

Table-1. Average values on the effect of species and cutting on DM and TNC percentages of 14 selected Italian ryegrass varieties of diploid and tetraploid

\begin{tabular}{|l|c|c|c|c|c|}
\hline \multicolumn{7}{|c|}{ Diploid } \\
\hline Species & DM \% & TNC \% & Cutting & DM \% & TNC \% \\
\hline 148 BQX & $19.7^{\text {bc }}$ & $16.2^{\mathrm{d}}$ & 1 & $17.4^{\text {cd }}$ & $17.7^{\mathrm{e}}$ \\
\hline 14LMD43 & $19.3^{\mathrm{c}}$ & $16.4^{\mathrm{d}}$ & 2 & $18.0^{\mathrm{c}}$ & $18.9^{\mathrm{d}}$ \\
\hline Bartento & $18.3^{\mathrm{d}}$ & $17.2^{\mathrm{b}}$ & 3 & $21.0^{\mathrm{b}}$ & $20.3^{\mathrm{b}}$ \\
\hline Kigezi & $20.0^{\mathrm{bc}}$ & $14.6^{\mathrm{f}}$ & 4 & $17.4^{\text {dd }}$ & $20.6^{\mathrm{a}}$ \\
\hline Maximus & $18.1^{\mathrm{d}}$ & $15.7^{\mathrm{e}}$ & 5 & $16.6^{\mathrm{d}}$ & $11.7^{\mathrm{g}}$ \\
\hline Sukari & $20.6^{\mathrm{ab}}$ & $17.0^{\mathrm{c}}$ & 6 & $17.2^{\text {cd }}$ & $18.6^{\mathrm{c}}$ \\
\hline SuperCharge & $21.0^{\mathrm{a}}$ & $23.1^{\mathrm{a}}$ & 7 & $29.4^{\mathrm{a}}$ & $12.3^{\mathrm{f}}$ \\
\hline SE & 0.329 & 0.063 & & 0.329 & 0.063 \\
\hline \multicolumn{5}{|c|}{ Tetraploid } \\
\hline Species & DM \% & TNC \% & Cutting & DM \% & TNC \% \\
\hline 214GQX & $17.9^{\text {cd }}$ & $16.2^{\mathrm{c}}$ & 1 & $16.6^{\mathrm{c}}$ & $17.6^{\mathrm{d}}$ \\
\hline AgriBoost & $19.4^{\mathrm{ab}}$ & $14.8^{\mathrm{f}}$ & 2 & $16.6^{\mathrm{c}}$ & $17.8^{\mathrm{c}}$ \\
\hline Agriton & $19.7^{\mathrm{a}}$ & $15.4^{\mathrm{e}}$ & 3 & $20.1^{\mathrm{b}}$ & $19.4^{\mathrm{a}}$ \\
\hline Barmulta & $18.5^{\mathrm{bcd}}$ & $16.0^{\mathrm{d}}$ & 4 & $17.0^{\mathrm{c}}$ & $18.9^{\mathrm{b}}$ \\
\hline GreenSpirit & $18.8^{\mathrm{abc}}$ & $15.5^{\mathrm{e}}$ & 5 & $16.4^{\mathrm{c}}$ & $9.3^{\mathrm{g}}$ \\
\hline Mona & $17.8^{\mathrm{d}}$ & $16.3^{\mathrm{b}}$ & 6 & $16.8^{\mathrm{c}}$ & $16.8^{\mathrm{e}}$ \\
\hline SupremeQ & $19.5^{\text {ab }}$ & $16.7^{\mathrm{a}}$ & 7 & $28.1^{\mathrm{a}}$ & $11.2^{\mathrm{f}}$ \\
\hline SE & 0.328 & 0.051 & & 0.328 & 0.051 \\
\hline
\end{tabular}

abcdefg: Means with different superscripts in the same column differ $(\mathrm{P}<0.05)$

SE: standard error

CL: cutting stage, DM: dry matter yield, TNC: total non-structural carbohydrates

At different cutting stages, the seventh cutting had the highest $(\mathrm{P}<0.05) \mathrm{DM}$ value $(28.1 \%)$ than all other cutting stages in tetraploid. The third cutting had the highest $(\mathrm{P}<0.05)$ concentration $(19.4 \%)$ as compared to all different cutting stages in the same tetraploid group. The different cutting stages and sampling days influenced the photosynthesis and respiration rate of the plants (Francis et al., 2002; Kagan et al., 2011). Indeed, different species varieties possess different TNC, fructan, glucose, fructose sucrose and starch (Brocklebank and Hendrỳ, 2006; Downing and Gamroth, 2007). Again, stage of plant development can lead to an increase in carbohydrates concentration in the plants (Francis et al., 2002). 
Effect of cutting stage and cultivar on average values of DM and TNC percentages of seven selected Italian ryegrass of varieties of diploid

The results of the effect of cutting and variety on average values of DM and TNC (total non-structural carbohydrates) percentages of seven selected Italian ryegrass of diploid are presented in Table 2 . Although the significant differences were observed, consistent effect on cutting stage on DM yield and TNC was not observed on average mean values. This can be attributed to the cuttings that reduced tillering that contributes to the dry matter yield of plants and plant normally respond differently after defoliation through tolerance mechanisms as an influence by different morphological and physiological characteristics of those varieties (Wen and Jiang, 2005). Seventh cutting in each variety had higher $(\mathrm{P}<0.05) \mathrm{DM}$ percentages when compared to all cutting stages within each variety. Within each cutting stage, SuperCharge had higher $(\mathrm{P}<0.05) \mathrm{DM} \%$ than all other species at the first cutting. SuperCharge (23.2\%) and Kigezi (23. $2 \%)$ has the highest $(\mathrm{P}<0.05) \mathrm{DM}$ yield at the third cutting. Sukari and SuperCharge varieties had the same (P>0.05) DM \% value as Maximus, 14LMD43 and ARC-148BQX varieties at the seventh cutting. Meissner et al. (1992) had similar DM values, as reported in this study. The authors reflected that DM content of 18 to $20 \%$ is recommended to maximise the intake of the diets. The feeding value of most Italian ryegrass varieties can be limited by a reduction in intake due to young grass at their vegetative stage (Marais et al., 1993).

Within species, ARC-148BQX at the third $(20.0 \%)$ and fourth $(20 \%)$ cutting stages had higher $(\mathrm{P}<0.05)$ TNC percentages when compared to other cutting stages of the same variety. The third cutting of Bartento had the higher $(\mathrm{P}<0.05)$ TNC concentration value $(23.2 \%)$ than all other cutting stages from the same variety. SuperCharge at the sixth cutting stage had the highest $(\mathrm{P}<0.05)$ TNC value $(28.0 \%)$ than all other cutting stages from the same variety.

Within each cutting stage, SuperCharge variety had the highest $(\mathrm{P}<0.05)$ TNC concentration than other varieties at the first $(24.1 \%)$, second $(27.2 \%)$, fourth $(27.4 \%)$, fifth $(17.5 \%)$, and sixth $(28.0 \%)$ cutting stages. As opposed to these results, management such as defoliation or cutting is known to be influencing the concentration of TNC. Formation of sugars, starch, proteins and other foods is dependent on photosynthetic processes of leaves (rarely of stems). If the plant is mowed or grazed, the plant will always utilised the carbohydrates reserved to recover from defoliation, and that will lead to the reduction of TNC concentration in the plants (Nelson, 1995; Prince, 2017).

Table-2. Cutting and variety effect on dry matter and TNC percentages of seven selected Italian ryegrass varieties of diploid

\begin{tabular}{|c|c|c|c|c|c|c|c|}
\hline \multicolumn{8}{|c|}{ DM \% } \\
\hline CL & 148BQX & 14LMD43 & Bartento & Kigezi & Maximus & Sukari & SuperCharge \\
\hline 1 & $16.8^{\mathrm{cB}}$ & $16.2^{\mathrm{cC}}$ & $17.3^{\mathrm{cBC}}$ & $17.4^{\mathrm{cBC}}$ & $15.5^{\mathrm{bcC}}$ & $18.7^{\mathrm{cAB}}$ & $20.2^{\mathrm{cA}}$ \\
\hline 2 & $17.4^{\mathrm{cBC}}$ & $17.1^{\mathrm{bcCD}}$ & $16.3^{\mathrm{cCD}}$ & $22.4^{\mathrm{bA}}$ & $14.8^{\mathrm{cD}}$ & $18.5^{\mathrm{cBC}}$ & $19.8^{\mathrm{cB}}$ \\
\hline 3 & $20.6^{\mathrm{bBC}}$ & $19.2^{\mathrm{bCD}}$ & $20.5^{\mathrm{bBC}}$ & $23.2^{\mathrm{bA}}$ & $17.9^{\mathrm{bD}}$ & $22.2^{\mathrm{bAB}}$ & $23.2^{\mathrm{bA}}$ \\
\hline 4 & $17.8^{\mathrm{cA}}$ & $18.3^{\mathrm{bcA}}$ & $16.6^{\mathrm{CAB}}$ & $17.2^{\mathrm{CAB}}$ & $15.2^{\mathrm{cB}}$ & $18.5^{\mathrm{cA}}$ & $18.2^{\mathrm{cdA}}$ \\
\hline 5 & $16.6^{\mathrm{cA}}$ & $17.1^{\mathrm{bcA}}$ & $15.9^{\mathrm{cA}}$ & $17.0^{\mathrm{cA}}$ & $15.3^{\mathrm{cA}}$ & $17.5^{\mathrm{cA}}$ & $16.8^{\mathrm{dA}}$ \\
\hline 6 & $17.0^{\mathrm{cAB}}$ & $18.5^{\mathrm{bcA}}$ & $15.8^{\mathrm{cB}}$ & $15.8^{\mathrm{cB}}$ & $16.6^{\mathrm{bcAB}}$ & $18.4^{\mathrm{cA}}$ & $18.4^{\mathrm{cdA}}$ \\
\hline 7 & $31.5^{\mathrm{aA}}$ & $28.5^{\mathrm{aBC}}$ & $26.1^{\mathrm{aC}}$ & $27.2^{\mathrm{aC}}$ & $31.7^{\mathrm{aA}}$ & $30.5^{\mathrm{aAB}}$ & $30.7^{\mathrm{aAB}}$ \\
\hline $\mathrm{SE}$ & \multicolumn{7}{|c|}{0.868} \\
\hline \multicolumn{8}{|c|}{ TNC \% } \\
\hline CL & 148BQX & 14LMD43 & Bartento & Kigezi & Maximus & Sukari & SuperCharge \\
\hline 1 & $15.3^{\mathrm{dD}}$ & $17.6^{\mathrm{cC}}$ & $18.1^{\mathrm{cB}}$ & $15.6^{\mathrm{cD}}$ & $15.2^{\mathrm{cD}}$ & $18.3^{\mathrm{cB}}$ & $24.1^{\mathrm{cA}}$ \\
\hline 2 & $18.5^{\mathrm{bD}}$ & $17.5^{\mathrm{cE}}$ & $20.2^{\mathrm{bB}}$ & $14.4^{\mathrm{dG}}$ & $15.5^{\mathrm{cF}}$ & $19.2^{\mathrm{bC}}$ & $27.2^{\mathrm{bA}}$ \\
\hline 3 & $20.0^{\mathrm{aC}}$ & $17.0^{\mathrm{dF}}$ & $23.2^{\mathrm{aA}}$ & $18.4^{\mathrm{aE}}$ & $21.0^{\mathrm{aB}}$ & $19.4^{\mathrm{bD}}$ & $23.1^{\mathrm{dA}}$ \\
\hline 4 & $20.0^{\mathrm{aC}}$ & $20.9^{\mathrm{aB}}$ & $20.1^{\mathrm{bC}}$ & $14.5^{\mathrm{dD}}$ & $20.3^{\mathrm{bC}}$ & $21.1^{\mathrm{aB}}$ & $27.4^{\mathrm{bA}}$ \\
\hline 5 & $12.3^{\mathrm{eAB}}$ & $12.0^{\mathrm{eB}}$ & $9.4^{\mathrm{eC}}$ & $9.3^{\mathrm{fC}}$ & $12.2^{\mathrm{dB}}$ & $9.3^{\mathrm{fC}}$ & $17.5^{\mathrm{eA}}$ \\
\hline 6 & $17.0^{\mathrm{cC}}$ & $18.4^{\mathrm{bB}}$ & $18.6^{\mathrm{cB}}$ & $16.2^{\mathrm{bD}}$ & $15.4^{\mathrm{cE}}$ & $16.5^{\mathrm{dD}}$ & $28.0^{\mathrm{aA}}$ \\
\hline 7 & $10.4^{\mathrm{fF}}$ & $11.4^{\mathrm{fD}}$ & $10.6^{\mathrm{dE}}$ & $13.8^{\mathrm{aC}}$ & $10.3^{\mathrm{eF}}$ & $15.2^{\mathrm{eA}}$ & $14.5^{\mathrm{fB}}$ \\
\hline $\mathrm{SE}$ & \multicolumn{7}{|c|}{0.165} \\
\hline
\end{tabular}

superscripts differ significantly $(\mathrm{P}<0.05)$

ABCDEFG: means in the same row with the different superscripts differ significantly $(\mathrm{P}<0.05) \mathrm{CL}$ : cutting stage, DM: dry matter yield, TNC: total non-structural carbohydrates

SE: standard error 
Effect of cutting and variety on average values of DM and TNC percentages of seven tetraploid Italian rye grass varieties

The results of the impact of cutting and variety on average values of DM and TNC percentages of seven Italian ryegrass varieties selected of tetraploid are presented in Table 3. Even though the consistent effect in cutting was not observed on dry matter yield and TNC percentages, there was a significant difference observed on mean values. Within each variety, the seventh cutting in each variety had higher $(\mathrm{P}<0.05)$ DM percentages when compared to all cutting stages within each variety.

Within each cutting stage, Agriton variety has higher $(\mathrm{P}<0.05) \mathrm{DM}$ percentage $(19.5 \%)$ than Mona variety at the first cutting. Agriton has the same $(\mathrm{P}>0.05) \mathrm{DM}$ $\%$ value as AgriBoost, GreenSpirit and SupremeQ varieties at the seventh cutting. Mona variety has the same ( $P>0.05)$ DM \% value as ARC-214GQX, Barmulta, GreenSpirit varieties at the seventh cutting. Within each variety, ARC-214GQX (21.7 \%), AgriBoost (18.3\%) and Barmulta $(20.2 \%)$ varieties at the third cutting stage had the highest $(\mathrm{P}<0.05)$ TNC percentages $(21.7 \%)$ when compared to other cutting stages from the same varieties. Mona and SupremeQ varieties at the fourth cutting stage had the highest $(\mathrm{P}<0.05) \quad$ TNC percentages $\quad(24.1$ and $21.8 \%$ respectively) when compared to other cutting stages from their respective same varieties.

Within each cutting stage, ARC-214GQX at the first cutting stage had the highest $(\mathrm{P}<0.05) \quad \mathrm{TNC}$ concentration (19.9\%) when compared to the other varieties from the same cutting stage. SupremeQ at the seventh cutting stage had the highest $(\mathrm{P}<0.05)$ TNC concentration $(13.2 \%)$ when compared to the other varieties in the same cutting stage. Comparably the values of TNC in tetraploid are almost similar to those of diploid varieties opposite to what was expected. Many of these TNC values, in general, are higher and also in comparison to those reported by Meeske et al. (2009) on the enhancer varieties. Compared to this study, Hopkins (2000) and Hopkins et al. (2003) reported lower values. Difference between plants is influenced by the fact that plants higher in TNC are unable to convert carbohydrate reserves into structural carbohydrates (Marais et al., 1993). Kellogg and Birchler (1993) highlighted that even though grasses might possess the same shoot anatomy and morphology different sizes of leaves will always be observed or linked with TNC concentration. The broadness of the leaves is known in the prevention of moisture evaporation and assist in the synthesis of carbohydrates when compared to thin or narrow leaves (Murphy et al., 2015; Ravhuhali et al., 2019). Plant species of higher TNC percentages can be selected as they influenced better taste, induce intake and milk production in dairy cows (Miller et al., 1999). The ryegrass is known to have low DM, which may reduce the DM intake of grass by the animal, especially dairy cattle.

Table-3. Cutting and variety effect on DM and TNC percentages of seven Italian ryegrass cultivars of tetraploid.

\begin{tabular}{|c|c|c|c|c|c|c|c|}
\hline \\
\hline & \multicolumn{7}{|c|}{ DM \% } \\
\hline CL & $214 \mathrm{GQX}$ & AgriBoost & Agriton & Barmulta & GreenSpirit & Mona & SupremeQ \\
\hline 1 & $16.6^{\mathrm{cdBC}}$ & $15.6^{\mathrm{cBC}}$ & $19.5^{\text {bcA }}$ & $16.3^{\mathrm{cBC}}$ & $16.2^{\mathrm{cBC}}$ & $14.3^{\mathrm{eC}}$ & $17.8^{\mathrm{cAB}}$ \\
\hline 2 & $15.9^{\mathrm{cdBC}}$ & $16.9^{\mathrm{cAB}}$ & $17.4^{\mathrm{cd} A \mathrm{~B}}$ & $16.0^{\mathrm{CBC}}$ & $16.6^{\mathrm{cABC}}$ & $14.8^{\mathrm{deC}}$ & $18.7^{\mathrm{cA}}$ \\
\hline 3 & $19.7^{\mathrm{bAB}}$ & $20.7^{\mathrm{bAB}}$ & $20.4^{\mathrm{bAB}}$ & $19.4^{\mathrm{bAB}}$ & $19.5^{\mathrm{bAB}}$ & $18.9^{\mathrm{bB}}$ & $21.8^{\mathrm{bA}}$ \\
\hline 4 & $16.7^{\mathrm{cAB}}$ & $16.5^{\mathrm{cAB}}$ & $15.3^{\mathrm{dB}}$ & $18.3^{\mathrm{bcA}}$ & $16.9^{\mathrm{cAB}}$ & $17.6^{\mathrm{bcAB}}$ & $17.5^{\mathrm{cA}}$ \\
\hline 5 & $14.4^{\mathrm{dB}}$ & $16.8^{\mathrm{cAB}}$ & $16.2^{\mathrm{dAB}}$ & $16.9^{\mathrm{cA}}$ & $16.8^{\mathrm{cAB}}$ & $16.9^{\mathrm{bcdA}}$ & $16.9^{\mathrm{cdA}}$ \\
\hline 6 & $17.0^{\mathrm{cAB}}$ & $17.4^{\mathrm{cAB}}$ & $19.1^{\mathrm{bcA}}$ & $16.9^{\mathrm{cAB}}$ & $18.1^{\mathrm{bcA}}$ & $15.6^{\mathrm{cdeB}}$ & $13.4^{\mathrm{dB}}$ \\
\hline 7 & $25.2^{\mathrm{aD}}$ & $32.0^{\mathrm{aA}}$ & $29.8^{\mathrm{aAB}}$ & $25.8^{\mathrm{aCD}}$ & $27.8^{\mathrm{aBC}}$ & $26.2^{\mathrm{aCD}}$ & $30.3^{\mathrm{aA}}$ \\
\hline \multirow[t]{2}{*}{ SE } & \multicolumn{7}{|c|}{0.868} \\
\hline & \multicolumn{7}{|c|}{ TNC \% } \\
\hline CL & $214 \mathrm{GQX}$ & AgriBoost & Agriton & Barmulta & GreenSpirit & Mona & SupremeQ \\
\hline 1 & $19.9^{\mathrm{bA}}$ & $14.5^{\mathrm{dG}}$ & $19.3^{\mathrm{bB}}$ & $17.4^{\mathrm{dE}}$ & $18.7^{\mathrm{aC}}$ & $15.6^{\mathrm{dF}}$ & $18.1^{\mathrm{dD}}$ \\
\hline 2 & $15.9^{\mathrm{dE}}$ & $16.3^{\mathrm{cD}}$ & $22.0^{\mathrm{aA}}$ & $18.1^{\mathrm{cC}}$ & $17.9^{\mathrm{bcC}}$ & $15.1^{\mathrm{eF}}$ & $19.3^{\mathrm{cB}}$ \\
\hline 3 & $21.7^{\mathrm{aA}}$ & $18.3^{\mathrm{aD}}$ & $17.2^{\mathrm{cF}}$ & $20.2^{\mathrm{aC}}$ & $17.6^{\mathrm{cdE}}$ & $20.8^{\mathrm{bB}}$ & $19.9^{\mathrm{bC}}$ \\
\hline 4 & $19.9^{\mathrm{bC}}$ & $16.3^{\mathrm{cE}}$ & $13.0^{\mathrm{fF}}$ & $19.7^{\mathrm{bC}}$ & $17.3^{\mathrm{dD}}$ & $24.1^{\mathrm{aA}}$ & $21.8^{\mathrm{aB}}$ \\
\hline 5 & $8.2^{\mathrm{fC}}$ & $9.9^{\mathrm{fB}}$ & $9.7^{\mathrm{gB}}$ & $8.1^{\mathrm{fC}}$ & $7.8^{\mathrm{fD}}$ & $11.6^{\mathrm{fA}}$ & $10.0^{\mathrm{gB}}$ \\
\hline 6 & $18.5^{\mathrm{cA}}$ & $17.1^{\mathrm{bC}}$ & $14.1^{\mathrm{dD}}$ & $17.6^{\mathrm{dB}}$ & $18.2^{\mathrm{bA}}$ & $17.2^{\mathrm{cC}}$ & $14.5^{\mathrm{eD}}$ \\
\hline 7 & $9.1^{\mathrm{eF}}$ & $11.5^{\mathrm{eC}}$ & $12.5^{\mathrm{eB}}$ & $10.7^{\mathrm{eD}}$ & $11.3^{\mathrm{eC}}$ & $9.9^{\mathrm{gE}}$ & $13.2^{\mathrm{fA}}$ \\
\hline SE & & & & 0.135 & & & \\
\hline
\end{tabular}
superscripts differ significantly $(\mathrm{P}<0.05)$

ABCDEFG: means in the same row with the different superscripts differ significantly $(\mathrm{P}<0.05) \mathrm{CL}$ : cutting stage, DM: dry matter yield, TNC: non-structural carbohydrates

SE: standard error

\section{Linear regression in establishing the relationship between cutting dates, and varieties on DM and TNC percentage}

There was no relationship between cutting interval and the parameter measured on both diploid and tetraploid Lolium multiflorum varieties (Figure 1 and 2). The 
cutting interval did not influence the DM yield and TNC concentration of both on diploid and tetraploid Lolium multiflorum varieties. Marais and Goodenough (2000) highlighted that the TNC content is always related to the amount of DM yield, and the improved varieties should have better TNC when compared to the other unimproved varieties. Indeed, a plant responds typically differently to defoliation, wowing or grazing. These results are in similar to those reported by Wen and Jiang (2005) who found no relationship between cutting and dry matter yields or different ryegrass varieties.

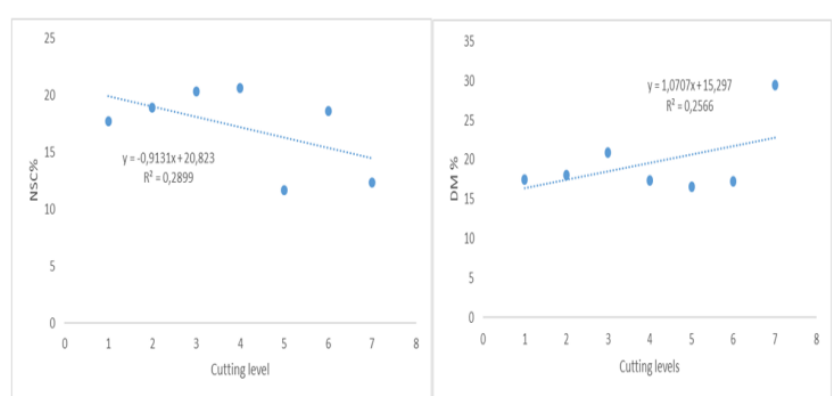

Figure-1. Linear regression in establishing the relationship between cutting dates, and DM and TNC percentage on diploid Lolium multiflorum varieties

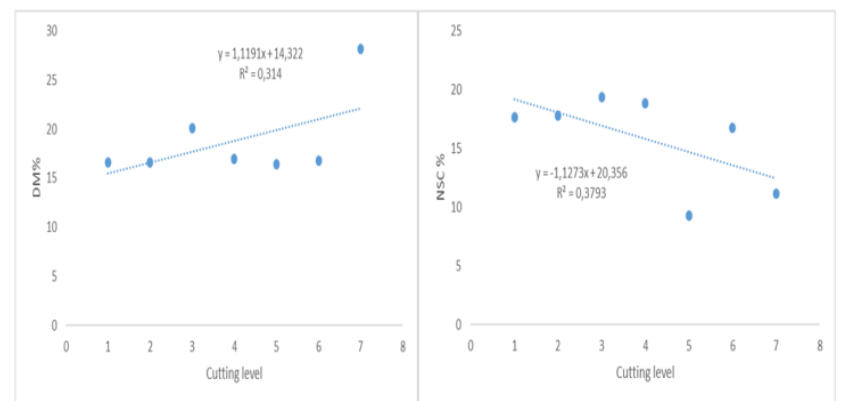

Figure-2. Linear regression in establishing the relationship between cutting dates, and DM and TNC percentage on tetraploid Lolium multiflorum varieties

\section{Conclusion}

Even though the consistent effect in cutting was not observed on dry matter yield and TNC percentages, there was a significant difference observed on mean values. Cutting had less influence on the DM yield and TNC concentration of both on diploid and tetraploid Lolium multiflorum varieties. Fifth cutting produced the DM yields below the recommended rate of $18-20 \%$ in both diploid and tetraploid variety groups. Again, fifth cutting had less TNC percentages in both varieties under diploid and tetraploid. The cutting stage can be reduced to four or five so as to allow the plant to regain its vigour after cutting/ defoliation in order to enforce the source-sink relationships.

\section{Acknowledgement}

The acknowledgements from the authors go to the Agricultural Research Council, South Africa for financial assistance. Thank the Cedara Forage Breeding staff is acknowledged for the hard work during the establishment and management of this research.

Disclaimer: None.

Conflict of Interest: None.

Source of Funding: Agricultural Research Council-Animal Production Institute (ARC-AP), South Africa.

\section{References}

Brocklebank KJ and Hendrỳ GAF, 2006. Characteristics of plant species which store different types of reserve carbohydrates. New Phytol. 112(2): 255-260.

Price AH, Cairns JE, Horton P, Jones HG and Griffiths $\mathrm{H}, 2002$. Linking drought-resistance mechanisms to drought avoidance in upland rice using a QTL approach: progress and new opportunities to integrate stomatal and mesophyll responses. J. Exp. Bot. 53: 989-1004.

Downing T and Gamroth M, 2007. Nonstructural Carbohydrates in Cool-season Grasses Special Report 1079-E. Oregon State University Extension Service, USA.

Francis SA, Chapman DF, Doyle PT, Leury BJ and Egan AR, 2002. Non-structural carbohydrate content of a perennial ryegrass cultivar bred for high sugar levels, compared to 'normal' perennial ryegrass and white clover. Anim. Prod. 24: 73-76.

Grace C, Boland TM, Sheridan H, Brennan E, Fritch $\mathrm{R}$ and Lynch MB, 2019. The effect of grazing versus cutting on dry matter production of multispecies and perennial ryegrass-only swards. Grass Forage Sci. 74: 437- 449. 
Harrison S, Fraser K, Lane G, Hughes D, Villas-Boas S and Rasmussen S, 2011. Analysis of highmolecular-weight fructan polymers in crude plant extracts by high-resolution LC-MS. Anal. Bioanal. Chem. 401: 2955-2963.

Hopkins C, 2000. The nutritive value of Italian ryegrass (Lolium multiflorum) selected for high dry matter and non-structural carbohydrate contents. PhD, University of Natal, Kwa-Zulu Natal South Africa.

Hopkins C, Marais, JP and Goodenough DCW, 2003. The performance of weaned lambs grazing high dry matter and nonstructural carbohydrate of Lolium multiflorum. S. Afr. J. Anim. Sci. 30: 6281.

Huner NPA, Öquist G, Hurry VM, Krol M, Falk S and Griffith M, 1993. Photosynthesis, photoinhibition and low-temperature acclimation in cold-tolerant plants. Photosyn. Res. 37: 19-39.

Jones EL and Roberts JE, 1991. A note on the relationship between palatability and watersoluble carbohydrates in perennial ryegrass. Irish J. Agric. Res. 30: 163-170.

Kagan IA, Kirch BH, Thatcher C, Strickland JR, Teutsch CD, Elvinger F and Pleasant RS, 2011. Seasonal and Diurnal Variation in Simple Sugar and Fructan Composition of Orchardgrass Pasture and Hay in the Piedmont Region of the United States. J. Equine. Vet. Sci. 31: 488-497.

Kellogg EA and Birchler JA, 1993. Linking phylogeny and genetics: Zea mays as a tool for phylogenetic studies. Syst. Biol. 42: 415-439.

Marais JP and Goodenough DCW, 2000. Nutritive value and dry matter yield of annual ryegrass 121C. S. Afr. J. Anim. Sci. 30: 74-75.

Marais JP, Goodenough DCW, de Figueiredo M and Hopkins C, 1993. Dry matter and non-structural carbohydrate content as quality parameters in a Lolium multiflorum breeding programme. Afr. J. Range Forage Sci.10: 118-123.

Marais JP, De Wit JL and Quicke GV, 1966. A critical examination of the Nelson-Somogyi method for the determination of reducing sugars. Anal. Bioanal. Chem.15: 373-381.

Meeske R, Botha PR, van der Merwe GD, Greyling JF, Hopkins C and Marais JP, 2009. Milk production potential of two ryegrass cultivars with different total non-structural carbohydrate contents. S. Afr. J. Anim. Sci. 39: 15-21.

Meissner HH, Du Preez MM, Enslin AD and Spreeth EB, 1992. Utilization of Lolium multiflorum by sheep. Influence of dry matter content and correlated factors on voluntary intake. J. Grassl. Soc. South. Afr. 9: 11-17.

Michell PJ, 1973. Relations between fibre and watersoluble carbohydrates contents of pasture species and their digestibility and voluntary intake by sheep. Aus. J. Exp. Agric. Anim. Husb. 13: 165170.

Miller LA, Theodorou MK, MacRae JC, Evans RT, Adesogan AT, Humphreys MO, Scollan ND and Moorby JM, 1999. Milk production and $\mathrm{N}$ partitioning responses in dairy cows offered perennial ryegrass selected for high water-soluble carbohydrate concentrations. S. Afr. J. Anim. Sci. 29: 281-282.

Murphy TM, Rost TL and Barbour MG, 2015. The Shoot System II: The Form and Structure of Leaves. Plant Biology. University of California, Davis, CA, USA.

Nelson JC, 1995. Photosynthesis and carbon metabolism. In Forage: an introduction grassland agriculture. Iowa State University Press Ames. 1: 40- 58.

NRC, 2000. Nutrient Requirements of Beef Cattle: Seventh Revised Edition: The National Academies Press. Washington, D.C. USA.

Pontis HG, 1989. Fructans and Cold Stress. J. Plant Physiol. 134: 148-150.

Prince KJ, 2017. Evaluating non-structural carbohydrate variation of cool-season grasses based on genotype, management and environment. Theses and Dissertations Plant and Soil Sciences. 85. University of Kentucky, USA.

Ravhuhali KE, Mlambo V, Beyene TS and Palamuleni LG, 2019. A comparative analysis of the morphology and nutritive value of five South African native grass species grown under controlled conditions. Afr. J. Range Forage Sci. 36: 67-70.

Regional Climate Development under Global Warming (regclim), 2005. Available at: http://regclim.met.no/index_en.html.

SAS, 2010. Statistical Analytical Systems, Users Guide. SAS Institute Inc., Cary, North Carolina, USA.

Tessema ZK, Mihret J and Solomon M, 2010. Effect of defoliation frequency and cutting height on growth, dry-matter yield and nutritive value of Napier grass (Pennisetum purpureum (L.) Schumach). Grass Forage Sci. 65: 421-430. 
Wadi A, Ishii Y and Idota S, 2004. Effects of Cutting Interval and Cutting Height on Dry Matter Yield and Overwintering Ability at the Established Year in Pennisetum Species,.Plant Prod. Sci. 7(1): 8896.

Wen Y and Jiang HF, 2005. Cutting effects on growth characteristics, yield composition and population relationships of perennial ryegrass and white clover in a mixed pasture. New Zeal. J. Agric. Res. 48: 349-358.

\section{Contribution of Authors}

Rakau PN: Conceptualization of the study, planting, data collection, Data analysis, Manuscript writing.

Ravhuhali KE: Conceptualization of the study, Data analysis, Manuscript writing.

Nzeru M: Conceptualization of the study, Data analysis. 